\title{
Protection of Informal Female Workers in Tourist Sector Company
}

\author{
Moh Hilal Nu'man, Rini Irianti Sundary*, Nurul Chotijah, Aep Saepulloh \\ Bandung Islamic University \\ Bandung, Indonesia \\ hilal.magisternotariat@gmail.com, *rinisundary@gmail.com, alqishasan@yahoo.co.id, aaepul915@gmail.com
}

\begin{abstract}
The development of tourism in the area of impacted areas caused many agricultural land to change function, and people main job of the residents in the area that became a place of tourism. It becomes more interesting when there are many women of productive age who are interested in earning a living in tourist areas either as traders, food supply suppliers or working with various types of jobs in tourism companies in their area. The absorption and empowerment of workers, especially women from the farming community, is a positive effect on the one hand, but on the other hand, problems arise related to the type of work, working time, wages and occupational health and safety. This study aims to examine the work carried out by female workers who come from the farming community in relation to the type of work, place of work, working time, payment of wages, and work health and safety for women workers who come from farming communities in tourist areas by taking samples in Dusun bambu in terms of Indonesian labor law. The research method used in this research is to use a normative juridical approach, which examines the symptoms that occur in society and then tests them based on concepts and laws and regulations. The types of data used are secondary, primary and tertiary data. The results showed that women workers, especially informal workers in the Dusun Bambu Tourism Area, worked 8 hours a day, in accordance with the provisions of Law No.13 of 2003, but there was no certainty regarding wages, workplaces in open spaces such as planting flowers. flowers in the garden, where the land is hilly, and there is also no certainty about health and safety guarantees.
\end{abstract}

Keywords—legal protection, female workers, informal

\section{INTRODUCTION}

The objective of this research is to examine the extent of regulations legislation protecting women workers is enforced in workplace., especially with regard to working time protection, workplace, wages, occupational health and safety. The rights of women in the fields of profession and manpower constitute rights that must be obtained by women before, during, or after doing the job stated by Abdul Hakim, 2019. Before it got work, a woman has the right to be given an opportunity the same with men to get the right job with ability, so that those women must be selected against him without any discrimination [1]. The principle of placing female workers in a company is that every woman worker has the same opportunity to choose, get or change jobs and earn an income A proper company in a particular match with expertise as well ability he has by not forgetting the nature of women who is gentle, conscientious and weaker [2].

The absorption and empowerment of workers, especially women from the farmer community, is a positive effect of the development of tourist areas in west Bandung regency, but on the other hand problems also arise related to the type of work, working time, wages and health and safety of work. So in this study will focus on researching How workplace arrangements and working time for female workers in Dusun Bambu Tourism Are reviewed from Law No.13 of 2003 About employment? And How about health insurance and job security for female workers who must be specially protected? This research was conducted with the aim of: Presenting and deepening the workplace and working time arrangements for working women from the farmer community in Dusun bambu tourism area reviewed from Law No.13 of 2003, and to analysis about the guarantee of work health and job accident guarantee for female workers who must be protected than man workers.

\section{METHODS}

Research in this writing uses a normative juridical approach conducted by examining library materials that are secondary data, namely tracing and conducting positive legal inventory to then research, review and find legal norms for a case in concreto. by researching library materials that are secondary data, [3] i.e. searching and doing positive legal inventory to then research, review and find the legal norm for a case in concreto.

The steps taken in the research are first to make an inventory of secondary data in the form of books, journals that are relevant to the focus of the research, classifying the data into qualitative data types, looking for primary data in the field through interviews with female workers at the research location and with the leadership. the company represented by a public relations manager. The research data were analyzed using qualitative analysis methods. 


\section{RESULTS AND DISCUSSION}

\section{A. The Concept of Working Women}

Talking about empowerment today is an important strategy in improving a woman's role and opportunities in improving her well-being, and is an effort to increase and realize their potential so that they are better able to be independent and work [4]. Such empowerment can be done through the coaching and improvement of women's skills Model approach to female empowerment which is often expressed is the Gender and Development model. This approach aims to understand the meaning of development for women in terms of self-reliance and internal strength of themselves. This model is more concerned with the development of women's organizations that lead to a level of awareness and education of the people.

As the times progressed, the phenomenon of women working was commonplace. Some women are even able to occupy important positions in several positions, ranging from Presidents, Ministers, and Managers. At this time, there is also a shift in the type of work done by women, so that the formerly dominant work is done by men, nowadays many are also done by women, from fine and prestigious work such as doctors, Judges, Prosecutors, Lecturers, entrepreneurs, to abusive jobs such as driver, pelvic floor, or factory employees and others. Woman involvement in this world of work can be both positive and negative.

In fact, working women experience more conflict than men, because women have different roles in the family. There are these differences because men's work in the family is more flexible, while women's work is more routine, such as child responsibility especially for children under the age of 12 [5]. Thus, women will still have to do a lot of things after doing activities in the office because of the responsibility.

The problem is that the low quality of human resources nationally is fundamental to women's resources, especially in rural and rural areas that are hard to touch by the eradication and renewal. Many people suspect that the low resources of women in Indonesia are due to gender unfairness, a traditional socio-cultural system that favors more men, and an interpretation of religious teachings that is more favorable and places men at a higher level than women.

It is interesting to observe, although normatively there is no discrimination against women in the development process, in fact the community that fills more than half of these ngara citizens has been left behind. The point isthat their interests (women) have been neglected. This is clearly reflected in the experience of the intensification of the agricultural sector in the $70 \mathrm{~s}$, which was done without taking into account the role of women. The intensification encapsulated in modernization ideology has removed women from agriculture. The dominance of women in subsistence agriculture has been shifted by the influx of capital. As a result, women were thrown onto ferries and non-agricultural sectors. The problem is sharpened when the non-agricultural sector is not quite ready to accommodate them due to inherent external and internal constraints [6].
Hasan Al-Banna said if primary needs require women to work for the sake of their families and children, they must meet islamic-defined requirements. He will be spared his slander. The main requirement is that his employment status is only to meet primary needs, not to meet other needs. In Islamic Law, among the scholars who say that women should not work outside the house is Abdullah ibn Ibrahim Jarullah. He said that women are not in the wisdom of working. He expressed this opinion based on the reality that exists in the woman herself and the decree stipulated by Islam.

Among the realities according to Abdullah ibn Ibrahim Jarullah is, women every month are approached by menstruation, for that they need a break. Women sometimes also conceive and give birth, which usually has difficulty in this case. After giving birth they are also required to breastfeed their child for up to two years. Based on Islamic concepts and other concepts, the research reviewed is the protection of occupational health, occupational safety, wages and special employment for female workers from the farmer community who now work in Dusun bamboo tourism.

\section{B. Working Time and Wages}

Law No. 13 of 2003 on Employment regulates several things, including about working hours, occupational safety and health, wages, messages, gon, termination of employment. employment in Indonesia and abroad. These regulations were created to protect workers and employers because they cover the rights and obligations of both in general. The regulation stipulated specifically in Law No. 13/2003 concerning employment article 77 to article 85. Where, Article 77 paragraph 1, Law No.13/2003 requires every employer to implement the provisions of working hours. This working hours' provision governs 2 systems, namely:

7 hours for working in 1 day or 40 working hours in 1 week for 6 business days in 1 week; or b. 8 working hours in 1 day or 40 working hours in 1 week for 5 business days in 1 week. In both working hours' systems are also given a working hours' limit of 40 (forty) hours in 1 (one) week. If it exceeds the terms of the working time, the usual working time is considered as overtime so that the worker or laborer is entitled to overtime wages.

The above working time conditions also only set work time limits for 7 or 8 hours a day and 40 hours a week and do not set when or when work starts and ends... Arrangements for the start and end of working hours each day and during the period of the week, shall be clearly regulated in accordance with the needs of the parties to the Employment Agreement, Company Regulation (PP) or Collective Labor Agreement (PKB. Therefore, if one of the parties usually wants to change the working hours then it must be based on an agreement with the worker representative or Workers Organization and socialize to the workers who are then presented in a joint agreement or PKB. However, these regulations certainly do not apply to some sectors and some types of jobs. And in its application of course this continuously executed work is carried out by the division of working time into shifts 
Based on the Decree of the Minister of Man Power and Transmigration, No. 233 on the Type and Nature of Work Carried Out Continuously, without following the provisions of working hours as stated in Law No. 13/2003. which in article 3 paragraph (1) governs that the continuous work is:

- jobs in the field of health care.

- jobs in transportation services.

- work in the field of transportation equipment repair services.

- jobs in tourism business.

- job in services postaux et de télécommunications

- job in the field of electricity supply, clean waterservice network, and oil and gas fuel supply

- jobs in convenience stores, shopping malls, and the like viii. jobs in the field of media.

- jobs in the field of security.

- work at conservation agencies xi. work that if discontinued will interfere with the production process, damage materials, and include maintenance/repair of production equipment.

Based on these regulations, the above types of work do not follow working hours in accordance with Law No. 13 of 2003, however, any excess hours worked by workers or workers in carrying out the above work, must be calculated as overtime to be paid because it is the right of the worker or worker protected by the Law [7]. In Dusun Bambu, based on research conducted before the covid-19 pandemic, there are 300 female workers. Of these, the study targeted female workers who worked in the workplace outside the office, namely those who worked as gardeners, parks, ticket guards, game park cleaners, which numbered about 200 people, and mostly from the surrounding population who originally worked as farmers or farmworkers. But after this covid, the number employed only revolves around 40 more people, they are housed without any guarantee and are not given any wages (source: Manager of human Resources Dusun Bambu).

At the time of the study under normal conditions, the female workers worked from 8 am to $3 \mathrm{pm}$, with a daily wage of $\operatorname{Rp~70,000~(Seventy~thousand~rupiah),~no~special~work~rest,~}$ and no lunch. Their wages are considered daily wages without any employment agreement. When viewed from labor regulations, working time can be said to be appropriate because it meets 8 hours of work, but between work time there are no special rules for prayer breaks and lunch. So they eat and pray between working hours.

\section{Security on Health and Safety}

Occupational safety and health protection is an important aspect of the working relationship, especially during the corona virus pandemic as it is today, along with the increasing risk of work, which must be ensured by the organizers of employment social security.

The results of the researchers on female workers in Dusun Bambu, because the target of this study is not formal workers, so there is no guarantee whatsoever for them, both occupational health and occupational safety, For the company health protection and safety of the work is the responsibility of each worker.

Women have a special protection in accordance with their reproductive function as stipulated in article 11 paragraph (1) of CEDAW letter $f$ that the right to occupational health and safety protection includes efforts to protect reproductive function.

Every woman has special rights relating to human rights that are recognized and protected by law. Women's Rights where women are categorized in vulnerable groups who have a special place in the guarantee of human rights protection. In the case of granting rights to women is the same as other rights as mentioned in the articles of the Human Rights Act but on that grounds it is further strengthened. The principles underlying women's rights include gender and anti-discrimination rights in the sense of having male-like rights in education, law, employment, politics, citizenship and rights in marriage and its obligations.

Female workers at tourist attractions, despite their informal status, should have the same right to protection over occupational health and safety. Of the 20 people sampled, all said that there was no guarantee whatsoever of their begi, but they were happy to be accepted to work at this tourist attraction, because the women of the workers, in the field of farming, the workers were no more starch. They don't want to demand their right of wages, health and safety, it is the responsibility of each worker for them.

\section{CONCLUSION}

The legal protection of female workers working in informal settings in tourist area Dusun bambu can be said to have not existed. But for them it does not become a problem, because their work motivation is still limited to "looking for additional income for the family", workers like this are generally in a weak position. This group of women workers, especially those who indeed are in a condition of utter deprivation or very poor, easily receive terms including wages or other employee benefits, that is determined unilaterally by the employer. Apart from that they generally no longer exist or less interested in attending trainings to increase knowledge for career development for example. They don't feel the need to compete and demand something. Apart from them, in general, there is little or nothing know her rights as partners who are actually equal to that of male workers as well as her special rights 
related to his natural functions that are not the same as the natural functions of men.

\section{REFERENCES}

[1] J.E. Finlay, "Women's reproductive health and economic activity: A narrative review," Word Development Journal, vol. 139, 2021.

[2] R. Pearson, Beyond women workers: gendering CSR, This World Quarterly, "Beyond Corporate Responsibility, Bussines Property, and Social Justice," vol. 28, pp. 731-749, 2007.

[3] R.H. Soemirto, Penelitian Hukum Pidana Pada Akhir Abad Ke-20. Bandung: Rineka Cipta, 1994
[4] A.S. Katz and Nico, "Perceived Workplace Health and Safety Climates: Associations With Worker Outcomes and Productivity," American Journal Of Preventife Medicine, vol. 7, Issue. 4, pp. 487-494, 2019.

[5] M.T. Ford, B.A. Heinen, and K.L. Langkamer, "Work and family satisfaction and conflict: a meta-analysis of cross-domain relations," Journal of applied psychology, vol. 92, no. 1, p. 57, 2007.

[6] J. Rabain, Pandangan Islam terhadap wanita bekerja, Jurnal Perempuan, Agama dan Gender. Pekanbaru: Pusat Studi Wanita Islam UIN SUSKA Pekanbaru, 2002.

[7] L. Husni, Pengantar Hukum KetenagaKerjaan Indonesia. Jakarta: PT Raja Grafindo Persada, 2001. 